\title{
National Survey of Medication Safety Practice: Patient Information at Primary Healthcare Centers/Community Pharmacies in Riyadh, Saudi Arabia
}

\author{
Yousef Ahmed Alomi, (iD The \\ Former General Manager of General \\ Administration of Pharmaceutical \\ Care, The Former Head, National Clini- \\ cal pharmacy and pharmacy practice, \\ The Former Head, Pharmacy R and \\ D Administration, Ministry of Health, \\ Riyadh, SAUDI ARABIA. \\ Rana Mohammed Alslim, Staff \\ pharmacist, Ministry of Health, \\ Riyadh, SAUDI ARABIA. \\ Manar Mohammed Alslim, Staff \\ pharmacist, Prince Sultan Military \\ Medical City, Riyadh, SAUDI ARABIA. \\ Khulud Abdulrahman Alamoudi, \\ Narcotic in-charge, Alhammadi hos- \\ pital Riyadh, SAUDI ARABIA. \\ Zainab Abdulmunem Almual- \\ lem, Saudi Food and Drug Authority \\ Riyadh, SAUDI ARABIA. \\ Adel Mehmas H. Alragas, Medi- \\ cal city-king Saud university, Riyadh, \\ SAUDI ARABIA.

\section{Correspondence: \\ Yousef Ahmed Alomi, \\ Bsc. Pharm, MSc. Clin Pharm, BCPS, BCNSP, \\ DiBA The Past General Manager of General Administration of Pharmaceutical Care \\ Head, National Clinical pharmacy and pharmacy practice Head, Pharmacy R \& D Administration Ministry of Health, P.O.BOX 100, Riyadh 11392, Riyadh, SAUDI ARABIA.}

Phone no: +966504417712

E-mail: yalomi@gmail.com

Received: 07-06-2018;

Accepted: 13-07-2018

Copyright: ๑) the author(s),publisher and licensee Pharmacology, Toxicology and Biomedical Reports. This is an open-access article distributed under the terms of the Creative Commons Attribution NonCommercial License, which permits unrestricted non-commercial use, distribution, and reproduction in any medium, provided the original work is properly cited.

This is an open access article distributed under the terms of the Creative Commons Attribution-NonCommercial-ShareAlike 4.0 License

\begin{tabular}{|c|c|}
\hline \multicolumn{2}{|c|}{ Access this article online } \\
\hline \\
\hline
\end{tabular}

\begin{abstract}
Objective: To explore patient's information regarding national medication safety Practice At Primary Healthcare Centers (PHCs) and Community Pharmacies (CPs) in Riyadh city, Kingdom of Saudi Arabia. Methods: This is a 4-month cross-sectional survey conducted on medication safety practice at PHCs and CPs in Riyadh city. In this study, the survey was adapted and modified from the Institution of Safe Medication Practice (ISMP) medication safety self-assessment for community/ambulatory pharmacy. It consists of a demographic section and 10 domains with 198 questions. The domains captured the following information: patient information; drug information; communication of drug orders and other drug information; drug labeling, packaging and nomenclature; use of medical devices; environmental factors; staff competency and education; patient education; quality processes; and risk management domain. The survey was conducted at the PHCs of the Ministry of Health and at CPs located in Riyadh city. This study is focused on the first domain, that is, patient information in PHCs and CPs in Riyadh city. Results: The survey was distributed to $13 \mathrm{PHCs}$ and $23 \mathrm{CPs}$. The average \pm Standard Deviation (SD) of all ISMP-self assessment items of medication safety practice at PHCs was $2.75 \pm 0.36$ (54.94 \%) $(95 \%$ confidence interval $(95 \% \mathrm{Cl})=2.55-2.95 ; P<0.05$; range $=2.04-3.38)$. The average $\pm S D$ score of all ISMP-self assessment items of medication safety practice at CPs was $3.14 \pm 0.42(62.86 \%)$ $(95 \% \mathrm{Cl}=2.90-4.38 ; P<0.05$; range $=2.40-.88)$. The average $\pm \mathrm{SD}$ score of patient information at PHCs was $2.80 \pm 0.467(56 \%)(95 \% \mathrm{Cl}=2.54-3.58 ; P<0.05$; range $=2.08-3.45)$, whereas that of the CPs was $2.60 \pm 0.667(52 \%)(95 \% \mathrm{Cl}=2.23-2.97 ; \mathrm{P}<0.05$; range $=1.36-3.96)$. Conclusion: The PHCs and PCs implemented almost half the of ISMP medication safety critical elements including the patient information related issue. Targeting to improve medication safety system at PHCs and CPs is highly recommended in the Kingdom of Saudi Arabia.
\end{abstract}

Key word: Medication, Safety, Patient, Information, Primary Healthcare Center, Community Pharmacy, Riyadh, Saudi Arabia.

\section{INTRODUCTION}

Over the past few years, healthcare services provided by the Ministry of Health $(\mathrm{MOH})$ hospitals, Primary Healthcare Centers (PHCs), Community Pharmacies (CPs), governmental non-MOH hospitals, university hospitals and private hospitals are expanding in the Kingdom of Saudi Arabia (KSA). In addition, the number of healthcare providers has increased with different specialties including physicians, nurses and pharmacists. PHCs have expanded from 1925 to 2282 centers. ${ }^{1,2}$ The number of pharmacists has increased from 131 to 430 at PHCs. ${ }^{1}$ In addition, the number of CPs and pharmacists have increased. The number of pharmacies in the KSA is currently around 7000 and is expected to reach around 12000 in the future. ${ }^{3}$ The number if patients visiting the PHCs have also increased from 40 to 58 million annually and two-thirds of them receive medications from their pharmacies. Because of the large number of prescriptions provided and dispensed annually, the number of medication errors has also increased. A local study explored the prescribing errors at $\mathrm{PHCs}^{4}$ and they found that the rate of error was around $17-33 \%$ among which the most common errors were related to antibiotics, intravenous fluids and bronchodilators. ${ }^{4}$

In addition, information regarding the patient's previous medical history guides the physician to prescribe the suitable drug, dose and route of administration. The patient's demographic and clinical data (e.g., age, weight, sensitivities, diagnosis and pregnancy status), as well as patient monitoring parameters (e.g., laboratory values, vital signs and other parameters), are critical parameters that help in deciding the nature of drug to be prescribed and the patient's basic illness processes. A previous study has reported that unfavorable medication events stem from professionals having inadequate data about the patient's medical history before prescribing, dispensing and administering drugs. ${ }^{5}$ About $29 \%$ of the prescribing mistakes alone are straightforwardly related to the lack of patient information. ${ }^{6}$

Another study reported on the medication safety practice at CPs. ${ }^{7}$ It showed most of the contributing factors related to dispensing errors were poor handwriting and lack time to discuss with the patients. ${ }^{7}$ Other studies have shown that only $18 \%$ of the CPs had awareness regarding medica- 
tion safety practice with an emphasis on pharmacovigilance system and another study showed that's of half of the studied pharmacist was not taking patient medication history. ${ }^{8,9}$

To predict medication errors and prevent them in the future at PHCs and Community Pharmacies (CPs), it necessary to implement the medication safety practice at PHCs and CPs. The system was founded by the Institution of Safety Medications Practice (ISMP). ${ }^{10}$ Several studies have explored the situation of healthcare institutions. The application of ISMP self-assessment of medications safety in the hospitals have shown improvement over the years; the number of preventive measures of medication errors has increased from 56 to 71 in the last survey. ${ }^{11,12}$ Another study was conducted on the self-assessment of safety regarding oncology medications practice. ${ }^{13}$ A local study on self-assessment of medications safety practice in hospitals was conducted during Hajj period. ${ }^{14}$ To the best of our knowledge, there is no regarding the self-assessment of medications safety practice in the PHCs and CPs across the KSA, Gulf and Middle Eastern countries. Therefore, in this study, we aimed to explore the medications safety practice in view of the patient information at PHCs and CPs in Riyadh, Saudi Arabia.

\section{METHODS}

This is a 4-month cross-sectional medication safety practice conducted at PHCs and CPs in Riyadh, KSA. The survey was adapted and modified from the Institution of Safe Medication Practice (ISMP) medication safety self-assessment for community/ambulatory pharmacy..$^{10}$ It consists of a demographic section and 10 domains with 198 questions. The 10 areas included patient information; drug information; communication of drug orders and other drug information; drug labeling, packaging and nomenclature; use of medication delivery devices; environmental factors; staff competency and education; patient education; quality processes; and risk management domain. The survey was conducted at PHCs of $\mathrm{MOH}$ and CPs located in Riyadh city. The responses were obtained using a 5-point Likert response scale system. The scoring key identified as number (1) is equal to (A): No activity to implement, (2) is equal to (B): Considered, but not implemented, (3) is equal to (C): Partially implemented in some or all areas, (4) is equal to (D): Fully implemented in some areas and (5) is equal to (E): Fully implemented throughout. The survey was distributed to the directors of the PHCs and CPs. The authors distributed the questionnaire and followed-up on a daily basis by physically visiting the pharmacies or by making a telephonic call. The questionnaire was prepared in an electronic format and was analyzed through the Survey Monkey system and Microsoft Excel version 10. The authors suggested some solutions to improve the scores of the medication safety practices as per the ISMP self-assessment items. The suggestions were based on the strategic plan of the General Administration of Pharmaceutical Care and Saudi Central Board of Accreditation for Healthcare Institutions (CBAHI) standards in Saudi Arabia. ${ }^{15,16}$ The 10 domains were divided into several parts for the ease of analysis, discussion and solution. Part one consisted of patient information; part two consisted of drug information; part three consisted of medication preparation and dispensing (Communication of drug orders and other drug information, drug labeling, packaging and nomenclature); part four consisted of medication administration (Drug standardization, storage and distribution, medication devices acquisition, use and monitoring); part five consisted of environmental factors, workflow and staffing, staff competency; and part six consisted of patient education, quality processes and risk management. In this study, our emphasis was on part one (Patient information).

\section{RESULTS}

The survey was distributed to 13 PHCs and 23 CPs. Majority of the PHCs was Type M1 and M3 (4 (30.8\%) and 3 (23.1\%) respectively). However, most of the CPs were large (8 (33.3\%)) and medium type (8 (33.3\%)). The majority of PHCs and CPs had accreditation from the Saudi Commission of Health Specialties (7 (70\%) and 20 (87\%), respectively). Most of PHCs dispensed more than 100 or fewer prescriptions on a daily basis $(7$ (53.9\%)), whereas CPs dispensed less than $20(11(45.8 \%))$. Most of the responders in PHCs were females $(9$ (69.2\%)) (4 (30.8\%) were male responders), whereas all the responders were males in CPs (25 $(100 \%))$. The majority of responders in PHCs was Saudi individuals (12 (92.3\%)), whereas those in CPs were non-Saudi individuals (25 (100\%)). Most of the responders in PHCs were in the age group of 30-44 years (9 $(69.2 \%)$ ), whereas those in the CPs were in the age group of 18-29 years $(15(62.5 \%))$. Most of the responders in PHCs had obtained a diploma, Bachelor of Science (B.Sc.) in Pharmacy, or Master of Science in Clinical Pharmacy (2 (22.2\%), 3 (33.3\%) and 2 (22.2\%), respectively). Most of the responders in CPs had obtained a B.Sc., in Pharmacy (22 $(88 \%))$. The majority of pharmacy staff did not have accreditation from the board of pharmaceutical specialties (8 (88.9\%) and 21 (91.3\%) working in the PHCs and CPs, respectively). The average score of all ISMP-self assessment items of medication safety at PHCs was $2.75 \pm 0.36(54.94 \%)$ $(95 \% \mathrm{CI}=2.55-2.95 ; P<0.05$; range $=2.04-3.38)$. The average score of all ISMP-self assessment items of medication safety at CPs was $3.14 \pm 0.42$ (62.86\%) $(95 \% \mathrm{CI}=2.90-4.38 ; P<0.05 ;$ range $=2.40-3.88)$ (Tables 1 and 2). The average score of patient information domain at PHCs was $2.80 \pm 0.467(56 \%)(95 \% \mathrm{CI}=2.54-3.58 ; P<0.05$; range $=2.08-3.45$. The average score of patient information domain at CP was $2.60 \pm 0.667(52 \%)$ (95\% CI $=2.23-2.97 ; P<0.05$; range $=1.36-3.96$ (Tables 1 and 2 ).

The items with high scores in patient information section at PHCs were "The pharmacy takes steps to effectively communicate with patients who are visually or hearing impaired" (3.45 (69\%)), "A standard process is followed to help ensure that medications are being dispensed to the proper patient" (3.42 (68.40\%)) and "Basic information about comorbid and/or chronic conditions, allergies, height and weight is obtained" (3.33 $(66.60 \%))$. The items with high scores in patient information section at CPs were "The pharmacy takes steps to understand cultural issues and overcome language barriers" (3.96 (79.2\%)), "The pharmacy takes steps to effectively communicate with patients who are visually or hearing impaired" $(3.5(70 \%))$ and "The clinical purpose of each prescription is ascertained before the medication is dispensed" (3.13 (62.6\%)) (Table 3). The items with low scores in patient information section at PHCs were "Patients in the pharmacy database are sent an annual survey to update clinical and demographic information in the computer system" (2.17 (43.4\%)), "Prescription orders cannot be entered into the pharmacy computer system until the patient's allergies" (2.25 (45\%)) and "A history of the use of herbal products, dietary supplements, homeopathic medications and alternative medicines is obtained for patients" (2.42 (48.4\%)). The items with low score in patient information section at CPs were "If a technician enters clinical information including allergies into the computer system, a pharmacist verifies that the information is accurate" (1.64 (32.80\%)), "A pharmacist enters clinical information including allergies into the computer system and properly codes the information to allow computer screening" (1.79 (35.80\%)) and "Prescription orders cannot be entered into the pharmacy computer system until the patient's allergies" (2.17 (43.40\%)) (Table 4).

\section{DISCUSSION}

The huge number of medications being prescribed to the patients has pushed the healthcare policy makers to establish systems to prevent drug-related problems. The national medication safety program founded in 2012 at $\mathrm{MOH}$ for all healthcare institutions including PHCs is one such initiative. ${ }^{17}$ The medication safety program was started in collaboration with the Institution of Safety Medications Practice (ISMP) from the 


\begin{tabular}{|c|c|c|c|c|c|c|c|c|c|c|c|c|c|c|}
\hline & $\begin{array}{l}\text { Medication Safety } \\
\text { Items }\end{array}$ & $\begin{array}{l}\text { Mean } \\
\text { score }\end{array}$ & SD & $\begin{array}{l}\text { Confidence } \\
\text { Level (95\%) }\end{array}$ & Range & Median & Mode & Percent & $\begin{array}{l}\text { SD } \\
\%\end{array}$ & $\begin{array}{l}\text { Confidence } \\
\text { Level }(95 \%)\end{array}$ & Range \% & $\begin{array}{c}\text { USA, } \\
2000 \\
\text { Scores } \\
\%\end{array}$ & $\begin{array}{c}\text { USA, } \\
2011 \\
\text { Scores } \\
\%\end{array}$ & $\begin{array}{c}\text { KSA, } \\
2017 \\
\text { Scores } \\
\%\end{array}$ \\
\hline I & Patient information & 2.80 & 0.467 & 0.258 & $\begin{array}{c}2.08- \\
3.45\end{array}$ & 2.83 & 3 & 56 & 9.34 & 5.16 & $\begin{array}{c}41.60- \\
69.00\end{array}$ & 43.00 & 60.00 & 55.00 \\
\hline II & Drug Information & 2.04 & 0.34 & 0.15 & $\begin{array}{c}1.50- \\
2.73\end{array}$ & 1.96 & 1.83 & 40.8 & 6.8 & 3 & $\begin{array}{c}30.00- \\
54.60\end{array}$ & 53.00 & 68.00 & 58.00 \\
\hline III & $\begin{array}{l}\text { Communication of drug } \\
\text { orders and other drug } \\
\text { information }\end{array}$ & 2.57 & 0.38 & 0.21 & $\begin{array}{c}1.92- \\
3.25\end{array}$ & 2.5 & 2.5 & 51.4 & 7.6 & 4.2 & $\begin{array}{c}38.40- \\
65.00\end{array}$ & 47.00 & 74.00 & 70.6 \\
\hline IV & $\begin{array}{l}\text { Drug Labeling and } \\
\text { Packaging and } \\
\text { Nomenclature }\end{array}$ & 2.57 & 0.41 & 0.22 & $\begin{array}{c}1.83- \\
3.08\end{array}$ & 2.71 & 2.92 & 51.4 & 8.2 & 4.4 & $\begin{array}{l}36.60- \\
61.60\end{array}$ & 61.00 & 74.00 & 71.4 \\
\hline V & $\begin{array}{l}\text { Drug Standardization, } \\
\text { Storage and Distribution }\end{array}$ & 2.35 & 0.41 & 0.18 & $\begin{array}{c}1.33- \\
3.09\end{array}$ & 2.25 & 2.25 & 47 & 8.2 & 3.6 & $\begin{array}{c}26.60- \\
61.80\end{array}$ & 73.00 & 81.00 & 70.80 \\
\hline VI & $\begin{array}{l}\text { Medication Devices } \\
\text { acquisition, Use and } \\
\text { Monitoring }\end{array}$ & 3.62 & 0.14 & 0.358 & $\begin{array}{c}3.45- \\
3.70\end{array}$ & 3.7 & 3.7 & 72.4 & 2.8 & 7.16 & $\begin{array}{c}69.00- \\
74.00\end{array}$ & 69.00 & 70.00 & 59.4 \\
\hline VII & $\begin{array}{l}\text { Environmental Factors, } \\
\text { Workflow and Staffing }\end{array}$ & 2.7 & 0.45 & 0.17 & $\begin{array}{c}1.55- \\
3.68\end{array}$ & 2.77 & 2.55 & 54 & 9 & 3.4 & $\begin{array}{c}31.00- \\
73.60\end{array}$ & 70.00 & 77.00 & 78.6 \\
\hline VIII & $\begin{array}{l}\text { Staff competency and } \\
\text { education }\end{array}$ & 3.02 & 0.298 & 0.18 & $\begin{array}{c}2.64- \\
3.55\end{array}$ & 3 & 3 & 60.4 & 5.96 & 3.6 & $\begin{array}{c}52.80- \\
71.00\end{array}$ & 53.00 & 64.00 & 73.80 \\
\hline IX & Patient Education & 3.04 & 0.365 & 0.15 & $\begin{array}{c}2.00- \\
3.73\end{array}$ & 3.09 & 3.09 & 60.8 & 7.3 & 3 & $\begin{array}{l}40.00- \\
74.60\end{array}$ & 48.00 & 68.00 & 75.00 \\
\hline $\mathrm{X}$ & $\begin{array}{l}\text { Quality Processes and } \\
\text { risk management }\end{array}$ & 2.76 & 0.35 & 0.12 & $\begin{array}{c}2.09- \\
3.50\end{array}$ & 2.82 & 3.00 & 55.2 & 7 & 2.4 & $\begin{array}{c}41.80- \\
76.00\end{array}$ & 51.00 & 72.00 & 63.60 \\
\hline & Average self-Assessment & 2.75 & 0.36 & 0.20 & $\begin{array}{c}2.04- \\
3.38\end{array}$ & & & 54.94 & 7.22 & 3.99 & & 56.00 & 71.00 & 67.68 \\
\hline
\end{tabular}

\begin{tabular}{|c|c|c|c|c|c|c|c|c|c|c|c|c|c|c|}
\hline & $\begin{array}{l}\text { Medication Safety } \\
\text { Items }\end{array}$ & $\begin{array}{l}\text { Mean } \\
\text { score }\end{array}$ & SD & $\begin{array}{l}\text { Confidence } \\
\text { Level }(95 \%)\end{array}$ & Range & Median & Mode & Percent & SD \% & $\begin{array}{l}\text { Confidence } \\
\text { Level (95\%) }\end{array}$ & Range \% & $\begin{array}{c}\text { USA, } \\
2000 \\
\text { Scores } \\
\%\end{array}$ & $\begin{array}{l}\text { USA, } \\
2011 \\
\text { Scores } \\
\%\end{array}$ & $\begin{array}{c}\text { KSA, } \\
2017 \\
\text { Scores } \\
\%\end{array}$ \\
\hline I & Patient information & 2.60 & 0.667 & 0.37 & $\begin{array}{c}1.36- \\
3.96\end{array}$ & 2.68 & Non & 52 & 13.34 & 7.4 & $\begin{array}{c}27.20- \\
79.20\end{array}$ & 43.00 & 60.00 & 55.00 \\
\hline II & Drug Information & 2.35 & 0.5 & 0.22 & $\begin{array}{c}1.61- \\
3.43\end{array}$ & 2.35 & 2.17 & 47 & 10 & 4.4 & $\begin{array}{c}32.20- \\
68.60\end{array}$ & 53.00 & 68.00 & 58.00 \\
\hline III & $\begin{array}{l}\text { Communication } \\
\text { of drug orders } \\
\text { and other drug } \\
\text { information }\end{array}$ & 2.44 & 0.35 & 0.195 & $\begin{array}{c}2.00- \\
3.09\end{array}$ & 2.57 & 2 & 48.8 & 7 & 3.9 & $\begin{array}{c}40.00- \\
61.80\end{array}$ & 47.00 & 74.00 & 70.6 \\
\hline IV & $\begin{array}{l}\text { Drug Labeling and } \\
\text { Packaging and } \\
\text { Nomenclature }\end{array}$ & 3.2 & 0.59 & 0.31 & $\begin{array}{c}2.20- \\
4.05\end{array}$ & 3.21 & non & 64 & 11.8 & 6.2 & $\begin{array}{c}44.00- \\
81.00\end{array}$ & 61.00 & 74.00 & 71.4 \\
\hline $\mathrm{V}$ & $\begin{array}{l}\text { Drug } \\
\text { Standardization, } \\
\text { Storage and } \\
\text { Distribution }\end{array}$ & 3.4 & 0.54 & 0.24 & $\begin{array}{c}2.22- \\
4.25\end{array}$ & 3.6 & 3.79 & 68 & 10.8 & 4.8 & $\begin{array}{c}44.40- \\
85.00\end{array}$ & 73.00 & 81.00 & 70.80 \\
\hline VI & $\begin{array}{l}\text { Medication Devices } \\
\text { acquisition, Use and } \\
\text { Monitoring }\end{array}$ & 2.78 & 0.23 & 0.569 & $\begin{array}{c}2.63- \\
3.05\end{array}$ & 2.68 & non & 55.6 & 4.6 & 11.38 & $\begin{array}{c}52.60- \\
61.00\end{array}$ & 69.00 & 70.00 & 59.4 \\
\hline VII & $\begin{array}{l}\text { Environmental } \\
\text { Factors, Workflow } \\
\text { and Staffing }\end{array}$ & 3.58 & 0.43 & 0.137 & $\begin{array}{c}2.63- \\
4.37\end{array}$ & 3.61 & 3.89 & 71.6 & 8.6 & 2.74 & $\begin{array}{c}52.60- \\
87.4\end{array}$ & 70.00 & 77.00 & 78.6 \\
\hline VIII & $\begin{array}{l}\text { Staff competency } \\
\text { and education }\end{array}$ & 4.15 & 0.20 & 0.12 & $\begin{array}{c}3.78- \\
4.53\end{array}$ & 4.11 & 4.11 & 83 & 4 & 2.4 & $\begin{array}{c}75.60- \\
90,6\end{array}$ & 53.00 & 64.00 & 73.80 \\
\hline
\end{tabular}


Alomi, et al:: Medication Safety Practice: Patient Information at PHCs and CP in KSA

\begin{tabular}{|c|c|c|c|c|c|c|c|c|c|c|c|c|c|c|}
\hline IX & Patient Education & 3.73 & 0.29 & 0.12 & $\begin{array}{c}3.11- \\
4.22\end{array}$ & 3.82 & 3.67 & 74.6 & 5.8 & 2.4 & $\begin{array}{c}62.20- \\
84.40\end{array}$ & 48.00 & 68.00 & 75.00 \\
\hline $\mathrm{x}$ & $\begin{array}{l}\text { Quality Processes } \\
\text { and risk } \\
\text { management }\end{array}$ & 3.20 & 0.38 & 0.13 & $\begin{array}{c}2.47- \\
3.89\end{array}$ & 3.31 & 3.37 & 64 & 7.6 & 2.6 & $\begin{array}{c}49.40- \\
77.80\end{array}$ & 51.00 & 72.00 & 63.60 \\
\hline & $\begin{array}{l}\text { Average self- } \\
\text { Assessment }\end{array}$ & 3.14 & 0.42 & 0.24 & $\begin{array}{c}2.40- \\
3.88\end{array}$ & & & 62.86 & 8.35 & 4.82 & & 56.00 & 71.00 & 67.68 \\
\hline
\end{tabular}

Table 3: The Highest Scores Items of Core Domain Essential Patient Safety of ISMP Medication Safety at Primary Healthcare Centers and Community Pharmacies.

\begin{tabular}{|c|c|c|c|c|c|c|c|c|c|}
\hline No & Key elements Core \# Essential patient information & $\begin{array}{l}\text { A } \\
1\end{array}$ & B & $\mathrm{C}$ & 4 & $\mathrm{E}$ & 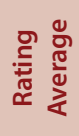 & 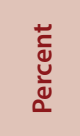 & 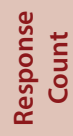 \\
\hline No & The highest scores items of Primary care center pharmacy & & & & & & & & \\
\hline 15 & $\begin{array}{l}\text { P) The pharmacy takes steps to effectively communicate } \\
\text { with patients who are visually or hearing impaired. }\end{array}$ & 1 & 1 & 3 & 4 & 2 & 3.45 & 69.00 & 11 \\
\hline 13 & $\begin{array}{l}\text { N) A standard process is followed to help ensure that } \\
\text { medications are being dispensed to the proper patient } \\
\text { (such as saying patient's full name aloud, verifying the } \\
\text { patient's name, address, phone number, etc.). }\end{array}$ & 3 & 0 & 2 & 3 & 4 & 3.42 & 68.40 & 12 \\
\hline 5 & $\begin{array}{l}\text { E) Basic information about comorbid and/or chronic } \\
\text { conditions (e.g., diabetes, hypertension, renal or liver } \\
\text { impairment, pregnancy, lactation, etc.), allergies, height } \\
\text { and weight is obtained when the patient is initially } \\
\text { encountered (via a questionnaire or other means) and } \\
\text { entered into the computer system. }\end{array}$ & 2 & 1 & 4 & 1 & 4 & 3.33 & 66.60 & 12 \\
\hline & The highest scores items of Community pharmacy & & & & & & & & \\
\hline 14 & $\begin{array}{l}\text { O) The pharmacy takes steps to understand cultural issues } \\
\text { and overcome language barriers that are present in the } \\
\text { population of patients served. }\end{array}$ & 3 & 1 & 3 & 4 & 13 & 3.96 & 79.20 & 24 \\
\hline 15 & $\begin{array}{l}\text { P) The pharmacy takes steps to effectively communicate } \\
\text { with patients who are visually or hearing impaired. }\end{array}$ & 4 & 3 & 3 & 5 & 9 & 3.50 & 70.00 & 24 \\
\hline 12 & $\begin{array}{l}\text { M) The clinical purpose of each prescription is } \\
\text { ascertained before the medication is dispensed to assure } \\
\text { that the prescribed therapy is appropriate for the patient's } \\
\text { condition and to help distinguish medications with } \\
\text { similar packaging and look-alike or sound-alike names. }\end{array}$ & 6 & 3 & 2 & 8 & 5 & 3.13 & 62.60 & 24 \\
\hline
\end{tabular}

Table 4: The Lowest Scores Items of Core Domain Essential Patient Safety of ISMP Medication Safety at Primary Healthcare Centers and Community Pharmacies.

\begin{tabular}{|c|c|c|c|c|c|c|c|c|c|}
\hline & Key elements Core \# Essential patient information & A & B & C & D & E & 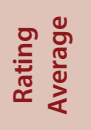 & 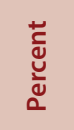 & 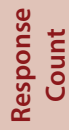 \\
\hline No & The lowest scores items of Primary care center pharmacy & & & & & & & & \\
\hline 4 & $\begin{array}{l}\text { D) A history of the use of herbal products, dietary supplements, } \\
\text { homeopathic medications and alternative medicines is obtained for } \\
\text { patients when initially encountered (via a questionnaire or other } \\
\text { means) and entered into the computer system. }\end{array}$ & 4 & 2 & 4 & 1 & 1 & 2.42 & 48.40 & 12 \\
\hline
\end{tabular}




\begin{tabular}{|c|c|c|c|c|c|c|c|c|c|}
\hline 9 & $\begin{array}{l}\text { J) Prescription orders cannot be entered into the pharmacy computer } \\
\text { system until the patient's allergies (or "no known allergies") have been } \\
\text { properly entered and coded (patient allergies is a required field). }\end{array}$ & 6 & 1 & 3 & 0 & 2 & 2.25 & 45.00 & 12 \\
\hline 6 & $\begin{array}{l}\text { F) Patients in the pharmacy database are sent an annual survey to } \\
\text { update clinical and demographic information in the computer system. }\end{array}$ & 6 & 1 & 3 & 1 & 1 & 2.17 & 43.40 & 12 \\
\hline & The lowest scores items of Community pharmacy & & & & & & & & \\
\hline 9 & $\begin{array}{l}\text { J) Prescription orders cannot be entered into the pharmacy computer } \\
\text { system until the patient's allergies (or "no known allergies") have been } \\
\text { properly entered and coded (patient allergies is required field). }\end{array}$ & 11 & 6 & 2 & 2 & 3 & 2.17 & 43.40 & 24 \\
\hline $8 \mathrm{~A}$ & $\begin{array}{l}\text { H) A pharmacist enters clinical information including allergies into } \\
\text { the computer system and properly codes the information to allow } \\
\text { computer screening. }\end{array}$ & 15 & 3 & 3 & 2 & 1 & 1.79 & 35.80 & 24 \\
\hline $8 \mathrm{~B}$ & $\begin{array}{l}\text { I) If a technician enters clinical information including allergies into the } \\
\text { computer system, a pharmacist verifies that the information is accurate } \\
\text { and that the names of allergens are spelled correctly and properly } \\
\text { coded to allow computer screening. }\end{array}$ & 13 & 7 & 0 & 1 & 1 & 1.64 & 32.80 & 22 \\
\hline
\end{tabular}

United State of America (USA). Self-assessment of medications safety practice at healthcare institutions was a part of this collaborative effort. This tool is used to predict the factors contributing to the medication errors and to monitor the current strategic plans at the General Administration of Pharmaceutical Care at $\mathrm{MOH} .{ }^{15}$ The author wishes to asses medication safety at PHCs and CPs by using the ISMP self-assessment tool. According to the results, there were more male responders in the CPs than that of PHCs. Most of the CP staff were pharmacists, whereas those in the PHCs were both pharmacists and pharmacy technicians. As a result, the owners in Saudi Arabia hire more of non-Saudi pharmacists as they demand less salary than Saudi professionals. There are no clinical pharmacists at CPs but few had a board of pharmaceuticals specialties certifications. The clinical pharmacy services are not well established at CPs. Some of the community pharmacists are interested in improving their career by obtaining more advanced certification in pharmacy practice. The finding of the study showed almost half of patient information key elements had existed with almost there is no difference between PHCs and CPs. This is expected because both PHCs and CPs do not have facilities for patient information. There is no network computer system of Computerized Physician Order Entry (CPOE). However, we expect that the results will improve after the implementation of Saudi Managed Care Pharmacy (SMCP) with New Saudi Vision 2030. 2,18 Both results of PHCs and CPs of patient information key element are similar to the previous study conducted in Saudi. ${ }^{14}$ Furthermore, our results were found to be better than that of the earlier study conducted in the USA and lower than that of recent study conduct in the USA. ${ }^{11,12}$ This is expected because the pharmacy services offered in the KSA is better but lesser than those offered in the USA. The highest scores obtained in the case of assessment statements that were related to the patient information at PHCs and CPs were found to be similar with respect to communication with the pharmacist. However, because more pharmacists at CPs with clinically oriented they can check and monitor the clinical relevant of patient information. Most of the lowest assessment scores were related to computerized patient information. This is expected because both seldom existing of CPOE and patient clinical information at CPs. To the best of knowledge, this study is the first to be conducted in the KSA,
Gulf and Middle Eastern countries regarding patient information. The study demonstrated the current practices related to patient information and medication safety. The CPOE with Saudi Managed Care Pharmacy (SMCP) implementation through the Saudization program is highly recommended to solve all problems related patient information in KSA.

\section{CONCLUSION}

The ISMP self-assessment of medication safety at PHCs and CPs in the KSA is first done in the Middle East and the rest of the world. Only half of the medication safety key elements implemented at PHCs and CPs. Approximately half of the patient information related to safety is missed in PHCs and CPs. The new technology and Saudi Managed Care Pharmacy maybe improve the patient information associated safety. Further studies with a high number of PHCs and CPs is required. Besides, Annual or biannually self-assessment of medication safety at PHCs and CPs is highly recommended in the Kingdom of Saudi Arabia.

\section{ACKNOWLEDGEMENT}

I want to thank all directors of all primary care pharmacists and community pharmacists for their cooperation and filled the survey.

\section{CONFLICT OF INTEREST}

The authors declare no conflict of interest.

\section{ABBREVIATIONS}

PHCs: Primary Healthcare Centers; CP: Community Pharmacy; CBAHI: Saudi Central Board of Accreditation for Heath Care Institutions; ISMP: Institution Safe Medication Practice; MOH: Ministry of Health; KSA: Kingdom of Saudi Arabia; USA: United States of America.

\section{ORCID ID}

Yousef Ahmed Alomi (iD https://orcid.org/0000-003-1381-628X. 


\section{REFERENCES}

1. Alomi YA, Alghamdi SJ, Alattyh RA. Primary Care Center Pharmacist's Workforce in Eleven-Year 2006-2016 at Ministry of Health in Saudi Arabia. J Pharm Pract Community Med. 2018;4(1s):S126-31.

2. Alomi YA. New Pharmacy Model for Vision 2030 in Saudi Arabia. J Pharm Pract Community Med. 2017;3(3).

3. Alaqeel S, Abanmy NO. Counselling practices in community pharmacies in Riyadh, Saudi Arabia: A cross-sectional study. BMC Health Serv Res. 2015;15(1):19.

4. Alsulami Z, Conroy S, Choonara I. Medication errors in the Middle East countries: A systematic review of the literature. Eur J Clin Pharmacol. 2013;69(4):9951008.

5. Velo GP, Minuz P. Medication errors: prescribing faults and prescription errors Br J Clin Pharmacol. 2009;67(6):624-8.

6. LesarTS, Briceland L, Stein DS. Factors related to errors in medication prescribing. JAMA. 1997;277(4):312-7.

7. Al-Arifi MN. Community pharmacists' attitudes toward dispensing errors at community pharmacy setting in Central Saudi Arabia. Saudi Pharm J. 2014;22(3):195-202

8. Al-Hazmi NN, II N. A Study of Community Pharmacists? Awareness and Contributions to Adverse Drug Reactions (ADRs) Reporting Systems in the Makkah, Kingdom of Saudi Arabia (KSA). J Clin Trials. 2013;3(1):1-5.

9. Ahmed NO, Al-wahibi NS. Knowledge Attitude and Practice towards Pharmaceutical Care in Community Pharmacy in Saudi Arabia. Br J Med Med Res. 2016;15(9):1-9.

10. Institute for Safe Medication Practices. 2011 ISMP Medication Safety Self Assessment for Hospitals. 2011;1-4. Available from: http://ismp.org/selfassess-
ments/Hospital/2011/definitions.pdf

11. Smetzer JL, Vaida AJ, Cohen MR, Tranum D, Pittman MA, Armstrong CW. Findings from the ISMP Medication Safety Self-Assessment for hospitals. Jt Comm J Qual Saf. 2003;29(11):586-97.

12. Vaida AJ, Smetzer JL, Lamis RL, Cohen MR, Kenward K. Assessing the state of safe medication practices using the ISMP medication safety self assessment $\circledast$ for hospitals: 2000 and 2011. Jt Comm J Qual Patient Saf . 2014;40(2):51-67.

13. Assessment S. ISMP International Medication Safety Self Assessment $₫$ for Oncology. 2012.

14. Alomi YA, Khayat AY, Jamil BM, Bamagaus YA, Mohammed H, Jumah A. National Survey of Hospital Medication Safety Practice during Mass Gathering (Hajj-2016) in Makkah, Saudi Arabia: Patient Information. J Pharm Pract Community Med. 2017;3(4s):29-35.

15. Alomi YA, Alghamdi SJ, Alattyh RA. Strategic Plan of General Administration of Pharmaceutical Care at Ministry of Health in Saudi Arabia 2012 - 2022. J Pharm Pharm Scien. 2015:1(13):1-8.

16. Medication management system. Saudi Center Board for Accreditation for Healthcare Institutions (CBAHI). 2016

17. Alomi YA. National Medication Safety Program at Ministry of Health in Saudi Arabia. J Pharmacovigil. 2015;3(5):e145.

18. Alomi YA, Alghamdi SJ, Alattyh RA. Saudi Managed Care Pharmacy (SMCP): New Initiative System of $\mathrm{MOH}$ Prescriptions Dispensed Through Community Pharmacies. J Pharm Pract Community Med. 2017;3(3). 